\title{
Profil Berpikir Aljabar Siswa SMP dalam Menyelesaikan Masalah Pola Bilangan
}

\section{Ni Putu N.K. Sari' ${ }^{1}$ Yusuf Fuad ${ }^{2}$, and Rooselyna Ekawati ${ }^{3}$}

\author{
1,2,3Universitas Negeri Surabaya, Jawa Timur, Indonesia
}

Corresponding Author: nisari16070785005@mhs.unesa.ac.id'; yusuffuad@unesa.ac.id ${ }^{2}$; rooselynaekawati@unesa.ac.id ${ }^{3}$

DOI: http://dx.doi.org/10.15294/kreano.v1 1i1.22525

Received : December 16 2019; Accepted: April 23 2020; Published: June 12020

\begin{abstract}
Abstrak
Penelitian ini bertujuan untuk mendeskripsikan profil berpikir aljabar siswa SMP dalam memecahkan masalah pola bilangan. Indikator berpikir aljabar yang digunakan, yaitu generalisasi, abstraksi, berpikir analitik, berpikir dinamik, pemodelan dan organisasi. Kelas 8B dipilih secara purposif dari dua kelas 8 pada SMP LabSchool Unesa Surabaya. Semua siswa kelas 8B, terdiri atas 21 laki-laki dan 9 perempuan, harus mengerjakan tes kemampuan matematika (TKM) dan tes pemecahan masalah (TPM). Hasil tes TKM, TPM dan dokumen nilai ujian tengah semester (UTS) mengidentifikasi 1 siswa berkategori matematika tinggi, 10 siswa berkategori matematika sedang dan 19 siswa berkategori matematika rendah. Selanjutnya, dipilih sebagai subjek penelitian, dengan sepersetujuan siswa, yakni seorang siswa laki-laki berkemampuan matematika tinggi dan masing-masing seorang siswa perempuan berkemampuan matematika sedang dan rendah. Data penelitian diperoleh dari jawaban TPM dan wawancara berbasis TPM. Keabsahan data diuji dengan triangulasi waktu. Hasil penelitian menunjukkan bahwa siswa berkemampuan tinggi memenuhi semua indikator berpikir aljabar dan semua langkah pemecahan masalah. Siswa kemampuan matematika sedang mampu menerapkan semua langkah pemecahan masalah, namun hanya memenuhi indikator generalisasi, abstraksi, pemodelan dan berpikir analitik. Siswa kemampuan matematika rendah masih mengalami kesulitan untuk menerapkan keempat langkah pemecahan masalah, dan hanya mampu memenuhi indikator abstraksi, berpikir dinamik, berpikir analitik, dan pengorganisasian. Dengan demikian kemampuan berpikir aljabar siswa SMP signifikan berpengaruh pada penyelesaian permasalahan pola bilangan. Oleh karena itu guru disarankan untuk lebih banyak memberi latihan untuk mengembangkan keterampilan berpikir aljabar siswa dalam memecahkan masalah pola bilangan.
\end{abstract}

Kata Kunci: berpikir aljabar; kemampuan matematika; masalah pola bilangan; pemecahan masalah

\begin{abstract}
This study describes algebraic thinking of secondary students in solving any number pattern problem. Six indicator of algebraic thinking are generalization, abstraction, analytical thinking, dynamic thinking, modeling and organization. Students of class $8 B$ are purposively chosen from grades 8 students of SMP LabSchool Surabaya. Students of class $8 B$, consists of 21 boys and 9 girls, has to answer the given mathematics ability and number patterns tests. Based on the tests results and the student's documentary record, there are only one student with high, 10 students with medium and 19 studens with low mathematics ability, respectively. Furthermore three volunteerly students, namely one student with high, medium and low mathematics ability respectively, are chosen as the research subjects. Then the data are collected from students' answers and interview data based on the number pattern test. The validity is justified by the triangulation time-based. The results emphasized that the high ability student is able to implement all problem solving procedures and all algebraic thinking indicators. The medium ability student satisfies all algebraic thinking's indicators, but cannot explicitly describe problem solving strategies. Meanwhile, the low ability student has still many difficuties in applying problem solving strategies and is only able to fulfill few algebraic thinking's indicators. Hence, the algebraic thinking influences significantly to the problem solving skills for the secondary students for solving the number patterns' problem. This result suggests that the teachers should give routinely exercises that are to improve the algebraic's thinking of secondary students in solving any number pattern problem.
\end{abstract}

Keywords: algebraic thinking; mathematics ability; solving problem; number pattern 


\section{PENDAHULUAN}

Pola bilangan telah digunakan tidak hanya dalam pembelajaran matematika tetapi juga dalam kehidupan sehari-hari. Pola bilangan atau pola juga merupakan salah satu topik penting dalam pendidikan matematika. Kemampuan siswa memahami pola bilangan memiliki dampak positif pada pencapaian hasil belajar matematika di tingkat selanjutnya (Papic, 2013; Warren et al, 2013). Terdapat berbagai macam pola bilangan, salah satu diantaranya jika dilihat dari objek-objek penyusunnya, yaitu bisa berupa bentuk geometri, simbol, huruf, angka, atau gabungan dari beberapa diantaranya.

Dalam belajar, siswa melakukan aktivitas berpikir. Berpikir merupakan suatu aktivitas mental yang melibatkan kerja otak. Berpikir logis yang dibutuhkan dalam matematika adalah berpikir aljabar (Gade, 2012; Lawrence et al., 2002; Nurhayati, 2017; Windsor, 2010). Berpikir aljabar merupakan kemampuan yang terdiri dari beberapa kegiatan berpikir, yaitu generalisasi, abstraksi, berpikir dinamik, berpikir analitik, pemodelan, dan organisasi (Lew, 2004). Berpikir aljabar merupakan proses mental seperti bernalar yang dimulai dengan yang belum dketahui, menggeneralisasi dan merumuskan hubungan antara besaran, serta mengembangkan konsep variabel (Booker \& Windsor, 2010; Van Ameron, 2002). Lebih lanjut, berpikir aljabar dapat dianggap sebagai kemampuan berpikir siswa dalam mengoperasikan sebuah kuantitas yang belum diketahui tetapi seolah-olah kuantitasnya sudah diketahui, yang berbeda dengan penalaran aritmetika yang melibatkan operasi pada kuantitas yang sudah diketahui (Patton, 2012; Windsor, 2010).

Berpikir aljabar tidak dapat terlepas dari kemampuan siswa dalam memecahkan masalah. Suatu masalah matematika dapat didefinisikan sebagai masalah kata, masalah cerita, atau masalah verbal (Phonapichat, 2013). Deskripsi dari suatu situasi, kata-kata atau dalam angka, yang membutuhkan jawaban kuantitatif atau numerik. Siswa harus menemukan cara untuk menyelesaikannya. Sesuatu dapat dipandang sebagai masalah jika siswa tidak dapat menyelesaikannya dengan secepatnya.
Setiap siswa mampu menyelesaikan masalah. Solusi muncul sesuai dengan kemampuan dan upaya siswa. (Gade, 2012; Saygili, 2017). Suatu pertanyaan merupakan masalah bagi siswa tersebut tetapi belum tentu merupakan masalah bagi siswa lain. Kemampuan dalam memecahkan masalah merupakan kemampuan yang ditunjukkan siswa dalam memahami, memilih pendekatan, dan melakukan strategi serta menyelesaikan untuk menemukan solusi dari sebuah soal atau permasalahan. Solusi terbaik dibuat oleh siswa yang dapat menggunakan strategi terbaik dengan mengevaluasi masalah. (Lubis, 2017). Dengan memecahkan masalah, siswa belajar menerapkan keterampilan matematika dengan cara-cara baru, mengembangkan pemahaman yang lebih dalam tentang ide-ide matematika dan merasakan pengalaman 'menjadi seorang matematikawan (Badger et al., 2012).

Setiap permasalahan yang dihadapi selalu membutuhkan suatu solusi, yang diupayakan dengan berbagai cara atau prosedur yang tersedia. Ada banyak cara yang dapat diterapkan untuk menyelesaikan suatu masalah sehingga masalah tersebut dapat dipecahkan (Walle, 2013). Memecahkan masalah merupakan pusat pembelajaran matematika, dengan memecahkan masalah maka siswa diberi banyak kesempatan untuk belajar menghubungkan ide matematika dan untuk mengembangkan pemahaman konseptual. (Gade, 2012; Widyastuti, 2015). Pada umumnya, tahapan pemecahan masalah yang sering digunakan adalah memahami masalah, membuat rencana, melakukan rencana, dan memeriksa kembali (Polya, 1975). Untuk menyelesaikan suatu masalah matematika diperlukan waktu yang relatif lama dari pada menyelesaikan soal rutin (Romli, 2016).

Salah satu materi matematika yang berkaitan dengan berpikir aljabar adalah pola bilangan. Pola bilangan dalam matematika dapat digambarkan sebagai keteraturan yang dapat diprediksi, biasanya melibatkan hubungan numerik, spasial atau logis. Pola bilangan merupakan fokus penting pada tahap awal perkembangan dalam berpikir aljabar. Pola-pola bilangan dalam aljabar dibagi ke dalam dua kategori, yaitu: pola pengulangan 
dan pola yang bertambah. (Mulligan, 2009; Warren et al, 2013). Pembelajaran yang melibatkan pola bilangan mempunyai peranan penting untuk membentuk dasar aljabar pada berbagai tingkat pendidikan. Secara khusus pola bilangan dipandang sebagai cara mendekati aljabar, karena merupakan langkah mendasar untuk menetapkan generalisasi yang merupakan esensi matematika..

Hasil penelitian Maulidiah (2010), Warsitasari (2015) dan Wilujeng (2017) memberikan dorongan dilakukannya penelitian untuk mendapatkan data empiris terkait profil berpikir aljabar siswa dalam memecahkan masalah pola bilangan. Dengan demikian, penelitian ini diharapkan dapat menjawab pertanyaan penelitian, yaitu "Bagaimanakah profil berpikir aljabar siswa SMP dalam menyelesaikan masalah pola bilangan yang ditinjau dari kemampuan matematika siswa?"

\section{METODE}

Penelitian ini adalah penelitian deskriptif dengan pendekatan kualitatif. Kelas $8^{\mathrm{B}}$ dipilih secara purposif dari dua kelas 8 pada SMP LabSchool Unesa. Semua siswa kelas $8^{B}$, terdiri atas 21 siswa laki-laki dan 9 siswa perempuan, diharuskan mengerjakan tes kemampuan matematika (TKM) dan tes pemecahan masalah (TPM) pada Januari-Februari 2019 dan hasilnya bersama nilai UTS Semester Ganjil 2018-2019, disajikan pada Tabel 1.

Berdasarkan hasil TKM, TPM, dan Nilai UTS di atas serta kesediaan siswa, dipilih seorang siswa dengan kemampuan matematika tinggi (laki-laki) sebagai $\mathrm{S}_{1}$, seorang siswa dengan kemampuan matematika sedang (perempuan) sebagai $\mathrm{S}_{2}$ dan seorang siswa dengan kemampuan matematika rendah (perempuan) sebagai $\mathrm{S}_{3}$.

Instrumen pendukung penelitian adalah soal TKM, soal TPM tentang permasala-

Tabel 1. Hasil Nilai Siswa

\begin{tabular}{cccccc}
\hline TKM & TPM & Nilai UTS & Kategori & Jumlah & Jenis Kelamin \\
\hline & & & Tinggi & 1 & Laki-laki \\
70 & 70 & 70 & Sedang & 3 & 2 Perempuan dan 1 Laki-laki \\
10 & 10 & 10 & Rendah & 10 & 4 Perempuan dan 6 Laki-laki \\
15 & 40 & 76 & Lain-lain & 16 & 6 Perempuan dan 10 Laki-laki \\
\hline
\end{tabular}

Tabel 2. Indikator Berpikir Aljabar

\begin{tabular}{|c|c|}
\hline $\begin{array}{c}\text { Komponen } \\
\text { Berpikir Aljabar }\end{array}$ & Aktivitas \\
\hline Generalisasi & $\begin{array}{l}\text { Mampu mendeskripsikan apa yang diketahui dan ditanyakan, mampu menyele- } \\
\text { saikan masalah dengan cara/pola yang sudah ditentukan sebelumnya serta mam- } \\
\text { pu memeriksa kembali langkah penyelesaian yang digunakan. }\end{array}$ \\
\hline Abstraksi & $\begin{array}{l}\text { Mampu mendeskripsikan alasan terkait dengan konsep matematika yang ditemu- } \\
\text { kan dalam soal, mampu mendeskripsikan simbol yang berhubungan dengan kon- } \\
\text { sep dan aturan dalam membuat renvana memecahkan masalah, mampu menger- } \\
\text { jakan operasi hitung yang simbolis berdasarkan yang diketahui, serta memeriksa } \\
\text { kembali operasi hitung berdasarkan yang diketahui. }\end{array}$ \\
\hline Berpikir Dinamis & $\begin{array}{l}\text { Mampu menjelaskan hubungan apa yang diketahui dan apa yang ditanyakan, } \\
\text { mampu menyelesaikan masalah dengan menggunakan strategi trial and error, } \\
\text { serta memeriksa kembali penyelesaian masalah dengan strategi trial and error. }\end{array}$ \\
\hline Berpikir Analitik & $\begin{array}{l}\text { Mampu menyelesaikan masalah dengan cara yang telah diketahui sebelumnya, } \\
\text { serta mampu memeriksa kembali dan menjelaskan penyelesaian masalah dengan } \\
\text { metode kerja mundur (backward method). }\end{array}$ \\
\hline Pengorganisasian & $\begin{array}{l}\text { Mampu menyederhanakan informasi yang diketahui dan ditanyakan, mampu me- } \\
\text { nyelesaikan masalah dengan menggunakan deduksi logis serta mampu menjelas- } \\
\text { kan rencana penyelesaian yang dipilih sesuai dengan masalah. }\end{array}$ \\
\hline Pemodelan & $\begin{array}{l}\text { Mampu menjelaskan situasi menggunakan diagram/gambar dalam membuat } \\
\text { rencana pemecahan masalah, rencana penyelesaian yang dipilih serta memeriksa } \\
\text { kembali penyelesaian yang sesuai dengan masalah. }\end{array}$ \\
\hline
\end{tabular}


han pola bilangan, dan pedoman wawancara. Semua instrumen pendukung divalidasi oleh dua orang dosen Jurusan Matematika FMIPA Unesa dan seorang guru matematika SMP Labschool Unesa, serta telah dinyatakan layak untuk digunakan.

\section{HASIL DAN PEMBAHASAN}

Diperoleh gambaran kemampuan berpikir aljabar siswa SMP dalam menyelesaikan masalah pola bilangan sebagai berikut.

\section{Profil Berpikir Aljabar Siswa Kemam- puan Tinggi dalam Memecahkan Masalah}

Berdasarkan 3 (tiga) permasalahan yang diberikan, S1 mampu mengetahui dengan baik informasi yang diketahui dari setiap masalah yang diberikan. S1 dapat mengkonstruk rumus sendiri dengan cara mencoba-coba (trial and error). S1 dapat menentukan dua strategi untuk menyelesaikan masalah yaitu menggunakan rumus Un (suku ke- $n$ ) dan melanjutkan pola pada barisan bilangan. Subjek S1 mampu menjawab semua masalah dengan baik namun selalu mengabaikan untuk menuliskan apa yang diketahui dan apa yang ditanyakan dari setiap masalah. Untuk deskripsi lebih detail, permasalahan pada soal nomor 2 dipilih karena S1 merasa permasalahan tersebut memiliki tingkat kesulitan yang cukup tinggi dibandingkan permasalahan lainnya. Permasalahan pada soal nomor 2 disajikan pada Gambar 1.

Pada gambar terlihat S1 sudah mengetahui dengan baik informasi yang diberikan pada soal dengan menuliskan kembali semua bagian= yang diketahui dan yang ditanyakan. S1 dapat menuliskan alternatif penyelesaian berdasarkan rumus yang diperoleh dari hasil coba-coba (trial and error). Pada tahap melaksanakan rencana, S1 menyelesaikan masalah dengan menggunakan rumus yang sudah ditemukan pada tahap sebelumnya. S1 menggunakan pola berbentuk gambar sebagai jawaban alternatif pada langkah memeriksa kembali. Berdasarkan wawancara dengan S1 didapat bahwa S1 memenuhi komponen: (1) generalisasi, yaitu mampu mengidentifikasi apa yang diketahui dan apa yang ditanyakan pada soal serta menyelesaikan masalah dengan pola yang sudah ditentukan; (2) abstraksi, yaitu mampu memahami konsep matematika dengan memberi alasan tentang apa saja yang diketahui dan yang ditanyakan, menggunakan simbol yang berhubungan dengan konsep dan aturan dalam memecahkan masalah, serta melakukan operasi hitung berdasarkan apa yang diketahui; (3) berpikir dinamis, yaitu mampu mengidentifikasi hubungan soal dengan apa yang ditanyakan dan yang diketahui, serta dapat menyelesaikan masalah dengan strategi trial and error; (4) berpikir analitis, yaitu mampu menyelesaikan masalah menggunakan metode kerja mundur (backward method) dengan menjelaskan langkah-langkah

2. Sebuah percetakan diminta mencetak tiket untuk sebuah konser musik di tahun 2019. Percetakan tersebut mencetak nomor tiket dengan urutan $1,5,6,11,17$. 28 agar terhindar dari tiket palsu. Berapakah dua nomor selanjutnya jika perusahaan tersebut ingin mencetak tiket lagi?

Gambar 1. Masalah pada soal nomor 2.

2

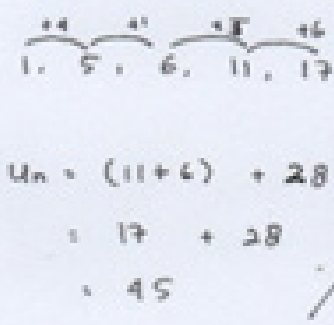

Gambar 2. Jawaban dari S1 untuk masalah pada soal nomor 2 
apa saja yang dilakukan; (5) pemodelan, yaitu mampu memodelkan situasi menggunakan gambar atau pola dalam memecahkan masalah; serta (6) pengorganisasian, yaitu mampu menyederhanakan informasi terkait dengan apa yang diketahui dan apa yang ditanyakan serta memilih rencana penyelesiaan yang sesuai dengan masalah. Hasil yang ditunjukan oleh $\mathrm{S}_{1}$ lebih lengkap dari hasil yang dilakukan oleh Warsitasari (2015) yang menyebukan bahwa siswa dengan kemampuan matematika tinggi melibatkan empat aktivitas berpikir aljabar yaitu generalisasi (menyatakan pola atau memformulasikan keumuman secara simbolis), abstraksi (mengekstraksi objek dan hubungan matematika berdasarkan generalisasi), pemodelan (merepresentasikan masalah dalam model matematika) dan berpikir dinamis (penggunaan variabel dalam melakukan manipulasi dinamis dari objek matematika.

Untuk menggali lebih dalam profil berpikir aljabar dari S1 dalam memecahkan masalah pola bilangan, berikut cuplikan wawancara dengan S1.

P: $\quad$ Apakah kamu bisa menjelaskan apa yang diketahui dan apa yang ditanyakan pada soal nomor 2 ?

S1: Iya, yang diketahui adalah urutan bilangan dari bilangan-bilangan dengan pola. Yang ditanyakan adalah suku (bilangan) selanjutnya.

P: Bagaimana cara kamu menyelesaikan soal nomor 2 tersebut?

S1: Dengan menggunakan rumus yang saya temukan dengan cara coba-coba.

P: Apakah menurut kamu ada cara lain dalam menyelesaikan soal tersebut? tika ada bagaimana? Coba jelaskan perlahan dan tidak usah terburu-buru.

S1: Ada, dengan cara manual yaitu dengan cara mengurutkan suku kemudian ditambah dengan beda suku sebelumnya

P: Apakah hasil akhir yang kamu peroleh dengan menggunakan rumus yang kamu temukan itu sama dengan menggunakan cara manual?

S1: lya, sama.

P: Bagaimana dengan masalah pada soalsoal lainnya? Apakah kamu bisa menyelesaikannya dengan baik?

S1: lya, soal lainnya tidak sesulit soal nomor 2 ini.

\section{Profil Berpikir Aljabar Siswa Kemam- puan Sedang dalam Memecahkan Masalah}

Subjek S2 mampu mengetahui dengan baik informasi yang diketahui dari masalah yang diberikan, namun $S_{2}$ belum mampu mencapai kriteria berpikir dinamis. Hal ini dikarenakan S2 tidak dapat menyelesaikan masalah dengan strategi trial and error serta belum mencapai kriteria pengorganisasian yaitu belum mampu menyelesaikan masalah berdasarkan rencana yang dibuat. S2 dapat menjawab soal nomor 1 dengan benar meskipun hanya melanjutkan barisan dengan cara menambahkan beda suku ke-7 untuk mendapatkan suku selanjutnya. dan Sedangkan untuk soal nomor 3, subjek S2 dapat menyelesaikannya dengan baik serta mampu menjelaskan langkah-langkah penyelesaiannya. Untuk deskripsi lebih detail, permasalahan pada soal nomor 2 dipilih karena S2 juga merasa bahwa soal tersebut memiliki tingkat kesulitan yang cukup tinggi.

Berikut penyelesaian masalah pada soal nomor 2 yang ditulis oleh $\mathrm{S} 2$.

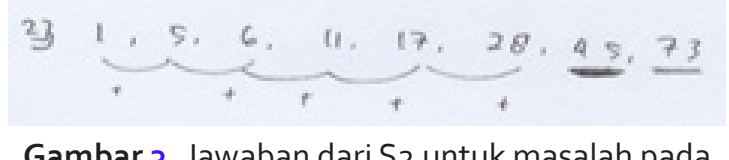

Gambar 3. Jawaban dari S2 untuk masalah pada soal nomor 2 .

Pada Gambar 3 terlihat bahwa S2 mengetahui dengan baik informasi yang diberikan pada soal dengan menuliskan kembali semua bagian-bagian yang diketahui dari soal yang diberikan. Akan tetapi S2 belum dapat menuliskan langkah penyelesaian yang sesuai dengan apa yang direncanakan. Berdasarkan hasil wawancara, S2 hanya memenuhi kriteria: (1) generalisasi, yaitu mampu mengidentifikasi apa yang diketahui dan ditanyakan pada soal; (2) abstraksi, yaitu mampu memahami konsep matematika dengan memberi alasan tentang apa saja yang diketahui dan yang ditanyakan, menggunakan simbol yang berhubungan dengan konsep dan aturan dalam memecahkan masalah, serta melakukan operasi hitung berdasarkan apa yang diketahui; (3) pemodelan, yaitu mampu memodelkan situasi menggunakan gambar atau pola dalam memecah- 
kan masalah dengan mengadopsi pola yang digunakan pada soal nomor 3 ; dan (4) berpikir analisis yaitu mampu menyelesiakan masalah menggunakan metode kerja mundur dengan menjelaskan langkah apa saja yang telah dilakukan. Hasil yang ditunjukkan oleh S2, yaitu siswa dengan kemampuan matematika sedang, masih lebih baik dibandingkan hasil dari Wilujeng (2017) yang menyatakan bahwa siswa kemampuan matematika sedang memiliki kemampuan yang kurang baik untuk konsep matematika,tidak bisa menyelesaikan masalah dengan baik dan tepat, serta proses pemodelan matematika masih kurang tepat sehingga dia cenderung menghentikan langkah penyelesaiannya karena bingung dengan proses perhitungan aljabar.

Untuk menggali lebih dalam profil berpikir aljabar dari S2 dalam memecahkan masalah pola bilangan, berikut cuplikan wawancara dengan $\mathrm{S} 2$.

P: Coba kamu jelaskan dengan perlahan apa saja yang diketahui dan yang ditanyakan pada soal nomor 2 ini?

S2: lya, yang diketahui adalah urutan bilangan dari suatu barisan. Yang ditanyakan adalah suku bilangan selanjutnya

P: Bagaimana cara kamu dalam menyelesaikan soal tersebut?

S2: Dengan menggunakan rumus Un.

P: Menurut kamu, apakah ada cara lain dalam menyelesaikan soal tersebut? Coba kamu ceritakan pelan-pelan saja.

S2: Ada, dengan cara manual yaitu dengan cara mengurutkan suku-suku yang diketahui kemudian ditambah dengan beda suku sebelumnya

P: Coba ceritakan, apa yang akan kamu lakukan untuk menyelesaikan soal nomor 2 tersebut?

S2: Dengan cara manual saja, soalnya saya ragujika menggunakan rumus

P: Bagaimana dengan soal lainnya? Apakah kamu menemui kesulitan dalam menyelesaikannya

S2: Soal lainnya masih bisa saya jawab, masih ketemu cara dan jawabannya selain nomor 2 ini yang masih bingung.

\section{Profil Berpikir Aljabar Siswa Kemam- puan Rendah dalam Memecahkan Masalah}

S3 memahami dengan baik informasi yang diketahui dari masalah yang diberikan. S3 menjawab soal nomor 1 dengan benar, namun belum mampu menjawab soal nomor 2 dan soal nomor 3 secara tepat, serta tidak menuliskan yang diketahui dan ditanyakan. S3 belum mampu menjelaskan situasi yang menggunakan gambar dalam membuat rencana pemecahan masalah, hal ini terbukti dari hasil wawancara dan jawaban tertulisnya. Untuk deskripsi lebih detail, permasalahan pada soal nomor 3 dipilih karena S3 merasa soal tersebut memiliki tingkat kesulitan yang cukup tinggi.

Soal nomor 3 yang dianggap oleh $\mathrm{S}_{3}$ memiliki tingkat kesulitan cukup tinggi. Berdasarkan gambar 5, terlihat bahwa S3 mengetahui dengan baik informasi yang diberikan pada soal dengan menuliskan kembali semua bagian-bagian yang diketahui dari soal yang diberikan. Akan tetapi S3 belum dapat menuliskan langkah penyelesaian dengan menggunakan diagram atau gambar. Berdasarkan jawaban tertulis dan hasil wawancara dengan

3. Ravi membantu ayah memasang keramik di rumah baru mereka. Pada baris pertama ia memasang 9 buah keramik, pada baris kedua ia memasang 16 buah keramik, pada baris ketiga ia memasang 25 keramik agar membentuk suatu pola tertentu. Berapa buah keramik yang harus Ravi pasang pada barisan ke delapan?

Gambar 4. Masalah pada soal nomor 3.

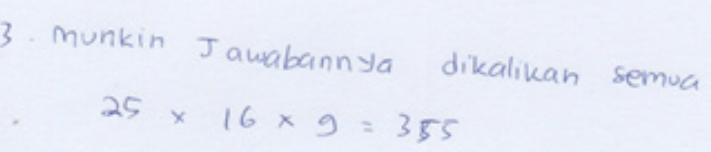

Gambar 5. Jawaban dari S3 untuk masalah pada soal nomor 3. 
$S_{3}$, diperoleh bahwa $S_{3}$ dapat mencapai indikator berpikir aljabar: (1) generalisasi, yaitu mampu mengidentifikasi apa yang diketahui dan yang ditanyakan pada soal dan memeriksa kembali langkah penyelesaian masalah dengan pola yang ditentukan; (2) abstraksi, yaitu memahami konsep matematika dan aturan seperti mmberi alasan tentang apa yang diketahui dan ditanyakan, melakukan operasi hitung berdasarkan apa yang diketahui; (3) berpikir dinamis, yaitu mampu mengidentifikasi hubungan soal dengan apa yang diketahui dan apa yang ditanyakan; (4) berpikir analitik, yaitu mampu menyelesaikan masalah menggunakan metode kerja mundur dengan menjelaskan langkah apa saja yang dilakukan; serta (5) pengorganisasian, yaitu mampu menyederhanakan informasi yang berkaitan dengan apa yang diketahui dan ditanyakan serta memilih rencana penyelesaian yang sesuai dengan masalah. S3 hanya mampu menjelaskan langkah penyelesaian dengan menduga-duga saja tanpa alasan serta tidak terampil menggunakan rumus atau pola tertentu dalam menyelesaikan masalah. Berikut hasil wawancara dengan S3 untuk permasalahan pada soal nomor 3 .

P: Apakah kamu bisa ceritakan, perlahanlahan saja, apa yang diketahui dan ditanyakan pada soal nomor 3 ini?

S3: lya, yang diketahui adalah urutan barisan jumlah ubin. Yang ditanyakan adalah banyaknya keramik pada barisan ke delapan

P: Coba ceritakan bagaimana kamu menyelesaikan soal tersebut?

S3: Di duga-duga saja. Sepertinya dikalikan saja semua angkanya.

P: $\quad$ Apakah kamu merasa ada cara lain untuk menyelesaikan soal tersebut?

S3: Tidak ada, dikalikan saja biar dapat jawabannya

P: $\quad$ Apa yang akan kamu lakukan untuk menyelesaikan soal tersebut?

S3: Dengan cara mengalikan $25 \times 16 \times 9$

P: Bagaimana dengan soal lainnya? Apakah kamu merasa bisa menyelesaikannya?

S3: Soal lainnya bisa saya kerjakan, kan hanya ditambah ganjil dan genap saja. Berbeda dengan soal nomor 3 ini yang harus dikalikan dan saya ragu dan merasa masih sulit.
Hal tersebut menguatkan temuan Booker dan Windsor (2010) yang menyatakan bahwa deskripsi verbal sudah separuh jalan untuk bisa menyelesaikan masalah secara aljabar. Dalam kasus di atas, S3 tampak ragu dengan beberapa jawaban dan hanya mampu menjelaskan langkah penyelesaian dengan menduga-duga saja tanpa alasan. Penelitian serupa juga menghasilkan simpulan yang karakteristiknya tidak berbeda (Lew, 2004; Lubis, 2017; Phonapicat et al, 2014).

\section{SIMPULAN}

Siswa berkemampuan matematika tinggi dapat mencapai semua indikator berpikir aljabar dan mempunyai cara lain dalam menyelesaikan masalah. Siswa kemampuan matematika sedang hanya mencapai 5 indikator berpikir aljabar, dan tidak mampu memenuhi indikator berpikir dinamis. Pada tahap merencanakan masalah, siswa kemampuan matematika sedang memahami tentang rumus barisan, namun pada saat melaksanakan rencana dia tidak menggunakannya dan hanya mengurutkan barisan serta menggambarkan pola selanjutnya untuk mendapatkan bilangan berikutnya. Sedangkan siswa berkemampuan matematika rendah hanya mencapai 5 indikator berpikir aljabar, yaitu generalisasi, asbtraksi, berpikir dinamis, berpikir analitis dan pengorganisasian. Pada tahap merencanakan dan penyelesaian masalah, dia menyebutkan bahwa soal hanya dapat dijawab dengan cara mengurutkan pola barisan bilangan dengan cara menduga-duga suku berikutnya yang ditambahkan dengan bilangan ganjil atau genap.

Berdasarkan hasil penelitian dan pembahasannya, guru disarankan untuk lebih sering melatih dan mengembangkan keterampilan siswa dalam berpikir aljabar untuk menyelesaikan permasalahan matematika. Pada akhirnya, siswa akan terampil berpikir aljabar yang menjadi dasar dalam menyelesaikan soal yang melibatkan pola bilangan. Selain itu, perlu dilakukan penelitian lebih lanjut dengan jenjang yang lebih tinggi, misalnya siswa SMA, agar profil berpikir aljabar bisa lebih detail dan pertumbuhan rasionalnya. 


\section{DAFTAR PUSTAKA}

Badger, M.S., Sangwin C.J and Hawkes T.O. (2012). Teaching Problem-Solving in Undergraduate Mathematics. Conventry University UK.

Booker, G. and Windsor, W. (2010). Developing Algebraic Thinking: Using Problem-Solving to Build from number and geometry in the primary school to the ideas that underpin algebra in high school and beyond. Procedia Social and Behavioral Sciences, 8, 411-419.

Gade, S. (2012). The Solving of Problems and the Problem of Meaning: The Case with Grade Eight Adolescent Students. In 13th ProMath Conference, September 2-4, 2011, in Umeå, Sweden (pp. 5-16). Umeå University.

Lawrence, A. and Hennessy, C. (2002) Lessons for Algebraic Thinking: Grade 6-8. Sausalito: Math Solution

Lew, H. C. (2004). Developing algebraic thinking in early grades: Case study of Korean elementary school mathematics. The Mathematics Educator, 8(1), 88-106.

Lubis, J.N, Panjaitan, A., Surya, E., \& Syahputra, E. (2017). Analysis Mathematical Problem Solving Skills of Student of the Grade VIII-2 Junior High School Bilah Hulu Labuhan Batu. International Journal of Novel Research in Education and Learning, 4(2), 131-137.

Mulligan, J. (2009). Awareness of Pattern and Structure in Early Mathematical Development. Mathematics Education Research Journal, 21(2), 33-49.

Nurhayati, D. (2017). Analysis of Secondary School Students' Algebraic Thinking and Math-Talk Learning Community to Help Students Learn. IOP Conf. Series: Journal of Physics: Conf. Series, 895 (2017) 012054.

Papic, M. (2013). A Mathematics Intervention: The Case of 4 year-old Rylan and Hilda. Procedia-Social and Behavioral Sciences, 106, 92-101.

Patton, B., \& De Los Santos, E. (2012). Analyzing algebraic thinking using "guess my number" problems. International Journal of Instruction, 5(1).

Phonapicat, P., Wongwanich, S. and Sujiva, S. (2014). An
Analysis of Elementary School Students' Difficulties in Mathematical Problem Solving. ProcediaSocial and Behavioral Sciences, 116, 3169-3174.

Polya, G. (1975). How to Solve It. New Jersey: Pricenton University Press

Romli, M. (2016). Profil Koneksi Matematis Siswa Perempuan Sma Dengan Kemampuan Matematika Tinggi Dalam Menyelesaikan Masalah Matematika. Jurnal Ilmiah Pendidikan Matematika, 1(2), 145-157.

Saygllı, S. (2017). Examining The Problem Solving Skills and The Strategies Used by High School Students in Solving Non-routine Problems. E-International Journal of Educational Research, 8(2), 91-114.

Van Ameron, B. (2002). Reinvention of Early Algebra. Developmental Research on the Transition from Arithmetic to Algebra. Freudenthal Instituut, Utrecht.

Walle, J.A. (2013). Elementary and Middle School Mathematics: Teaching Developmentally. New Jersey: Pearson.

Warren, E., Miller, J., \& Cooper, T. J. (2013). Exploring young students' functional thinking. PNA, 7(2), 75-84.

Warsitasari. (2015). Berpikir Aljabar Dalam Pemecahan Masalah Matematika. Jurnal APOTEMA, 1(1), 1-17.

Widyastuti, R. (2015). Proses berpikir siswa dalam menyelesaikan masalah matematika berdasarkan teori Polya ditinjau dari adversity quotient tipe climber. Al-Jabar: Jurnal Pendidikan Matematika, 6(2), 183-194.

Wilujeng, H. (2017). Profile Of Student Algebra Thinking Ability Based On Mathematical Preliminary Skills. International Journal of Research Granthaalayah, 5(11), 210-216.

Windsor, W. (2010). Algebraic Thinking: A Problem Solving Approach. Proceedings of the $33^{\text {rd }}$ Annual Conference of the Mathematics Education Research Group of Australasia. Downloaded from http:// hdl.handle.net/10072/36557. 